\title{
INVESTIGATION OF THE SWIRL EFFECT ON ENGINE USING DESIGNED SWIRL ADAPTER
}

\author{
A.K.M. MOHIUDDIN \\ Mechanical Engineering Department, Kulliyyah of Engineering, \\ International Islamic University Malaysia (IIUM), \\ Jalan Gombak, 53100, Kuala Lumpur, Malaysia. \\ mohiuddin@iium.edu.my
}

\begin{abstract}
Swirl is the rotational flow of charge within the cylinder about its axis. The engine used in this investigation is a basic Double Overhead Camshaft (DOHC) which has a capacity of $1597 \mathrm{cc}$ and installed with a total of 16 valves developed by Malaysian car manufacturer PROTON. The swirl adapter is placed inside the intake port of the Engine. The Adapter angle is set to $30^{\circ}$ to force the charge to bounce off the wall of the port to create swirl. The objective of this paper is to find the effect of swirl on the engine and to compare it with the normal turbulence mixing process. The swirl effect analysis is done by using the GT-SUITE which has a standard swirl flow embedded in the software. The effect is simulated on the GT-SUITE and it is found that the swirl affects the engine in reducing the fuel consumption and increasing the volumetric efficiency. The experimental result shows that the effect of swirl increases the power as well as torque in the idle and cruising speed conditions in comparison with normal turbulence. But it decreases rapidly in the acceleration speed. This happens due to the inability of the swirl adapter to generate swirl at higher wind flow velocity during the higher throttle opening condition.
\end{abstract}

\begin{abstract}
ABSTRAK: Pusar merupakan aliran putaran cas melingkungi silinder pada paksinya. Enjin yang digunakan untuk penyelidikan ini merupakan Enjin Aci Sesondol Stas Kembar (Double Overhead Camshaft (DOHC)) asas, yang mempunyai kapasiti 1597 cc. Ia dipasangkan dengan 16 injap yang dibangunkan oleh pembuat kereta Malaysia, PROTON. Penyesuai pusar diletakkan di dalam masukan liang enjin. Sudut penyesuai di tetapkan pada $30^{\circ}$ untuk memaksa cas supaya melantun kepada dinding liang agar membentuk pusaran. Tujuan tesis ini ditulis adalah untuk mendapatkan kesan pusar ke atas enjin dan membandingkannya dengan proses percampuran gelora normal. Analisis kesan pusaran dilakukan dengan menggunakan GT-SUITE yang mempunyai aliran pusar yang telah dipiawaikan di dalam perisian tersebut. Kesan tersebut disimulasikan menggunakan GT-SUITE dan didapati bahawa pusaran mengakibatkan penggunaan bahan api yang berkurangan dalam enjin dan juga meningkatkan kecekapan isi padu. Keputusan eksperimental menunjukkan kesan pusaran meningkatkan kuasa, daya kilas dalam keadaan melahu dan laju jajap dibandingkan dengan keadaan golakan normal. Walaupun begitu, ia berkurangan secara mendadak semasa pecutan kelajuan. Ini berlaku disebabkan oleh ketakdayaan penyesuai pusar untuk menghasilkan pusaran pada aliran angin halaju semasa keadaan bukaan mendikit luas.
\end{abstract}

KEYWORDS: swirl adapter; rotational flow; CAMPRO engine; volumetric efficiency; GTSUITE; fuel consumption 


\section{INTRODUCTION}

The main objective of this work is to investigate the effect of swirl on Proton's CAMPRO Engine Model 1.6 L. The CAMPRO engine is a basic Double Overhead Camshaft (DOHC) which has a capacity of $1597 \mathrm{cc}$ and installed with a total of 16 valves. The bore and stroke dimensions of each cylinder are $76 \mathrm{~mm}$ and $88 \mathrm{~mm}$ respectively. It is claimed to produce $110 \mathrm{bhp}(82 \mathrm{~kW}) @ 6500 \mathrm{RPM}$ and $148 \mathrm{Nm}$ of torque [1]. Extensive investigation of the swirl effect on CAMPRO engine is performed using GT-Power - a solver of GT-Suite. GT-SUITE is an integrated set of computer-aided engineering (CAE) tools developed by Gamma Technologies, Inc. to address engine and power train design [2]. These tools are contained in a single executable form which is essential to its use in "Integrated Simulations". GT-SUITE comprised of six solvers (GT-Power, GT-Drive, GT-Vtrain, GT-Cool, GT-Fuel, and GT-Crank), a model-building interface (GT-ISE), a powerful post-processing package (GT-POST), and a collection of supporting tools [3]. The solvers of GT SUITE are:

1. GT POWER - Engine simulation for performance and acoustics analysis.

2. GT DRIVE - Vehicle performance and cycle analysis for fuel economy and emissions and driveline components dynamics.

3. GT VALVE TRAIN - Valve train kinematics, dynamics and tribology, camshaft vibrations, cam design.

4. GT FUEL - Injection system pressure and flow dynamics, hydraulic system analysis.

5. GT COOL - Engine heat management and cooling system analysis.

6. GT CRANK - crankshaft dynamics and torsional vibrations, engine balance, block vibrations, mounts, bearing oil films

7. GT POST - viewing the results of the simulation and customizing plots.

GT-ISE provides the user with the graphical user interface (GUI) that is used to build models as well as the means to run all GT-SUITE applications.

Swirl is the rotational flow of charge within the cylinder about its axis [4]. Swirl is usually defined as organized rotation of the charge about the cylinder axis. Swirl is created by bringing the intake flow into the cylinder with an initial angular momentum.

There are two general ways of producing swirl during the induction process. Firstly, the flow is discharged into the cylinder tangentially towards the cylinder wall, where it is deflected sideways and downward in a swirling motion. In the other one, the swirl is largely generated within the inlet port: the flow is forced to rotate about the valve axis before it enters the cylinder. The directed port and the deflector wall port are two common ways of achieving this result. The directed port brings the flow toward the valve opening in the desired tangential direction. Its passage is straight and due to the other cylinder head requirements restricts the flow area and it results in a relatively low discharge coefficient. The deflector wall port uses the port inner side wall to force the flow preferentially through the outer periphery of the valve opening, in a tangential direction. Since only one wall is used to obtain a directional effect, the port areas are less restrictive.

\section{ENGINE SIMULATION USING GT-SUITE}

A GT-Model is created to model the CAMPRO engine. The model data were referred from Proton Powertrain department database. However, some data were taken from default 
value because of the insufficient information on the base engine. The engine model was first constructed using default values from the tutorial that is available in the GT SUITE. Then, the data from the CAMPRO is put into the model. Figure 1 shows the model of the CAMPRO in GT Power.

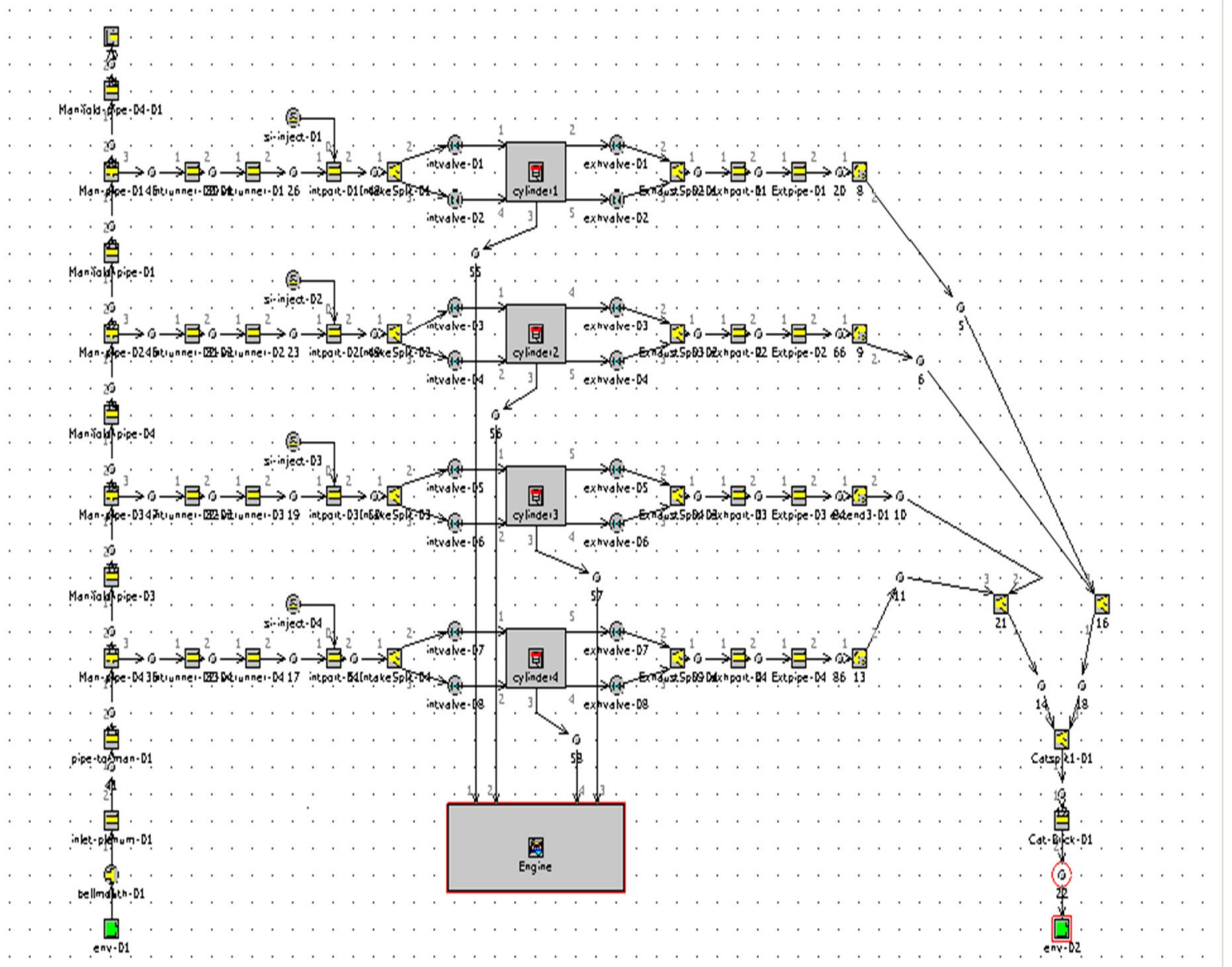

Fig. 1: CAMPRO model in GT Power.

The design process of the engine is as follows:

- The inlet and outlet boundary conditions are described by setting the EndEnvironment object

- The intake and exhaust runner are created using pipe object.

- The FStateInit template object is referred to the init object. It is the initial condition for the pipe object at the start of the simulation.

- Intake and exhaust ports are created using the pipe object. The created objects are cloned to create the other ports.

- The cylinder is created using the EngCylinder object. The cylinder geometry is set in the Cylinder Geometry Object under the name of geom.

- Cylinder wall attributes are defined in the twal object under EngCylTWall template.

- Cylinder heat transfer attributes are defined in the htr object under EngCylHeatTr template. 
- Cylinder combustion attributes are defined in the comb object under EngCylCombSIWiebe template.

- Fuel injection attributes are defined in the si-inject object under InjAFSeqConn template.

- The cranktrain is created using the cranktrain object under the EngineCrankTrain template.

- The friction attributes are defined. The friction object in the cranktrain main tab is named friction.

- The parts are connected by creating links between each of them.

- Then the components are cloned to produce a 4 cylinder model.

- After the model is built, the simulation is run.

- GT-Post is opened for result analysis.

\section{SWIRL}

Swirl is usually defined as organized rotation of the charge about the cylinder axis. Swirl is created by bringing the intake flow into the cylinder with an initial angular momentum. While some decay in swirl due to friction occurs during the engine cycle, intake generated swirl usually persists through the compression, combustion, and expansion process. In engine design with bowl-in-piston combustion chambers, the rotation motion set up during intake is substantially modified during compression. Swirl is used in diesels and some stratified-charge engine concepts to promote more rapid mixing between the inducted air charge and the injected fuel. Swirl is also used to speed up the combustion process in spark-ignition engines. In two-stroke engines, it is used to improve scavenging. In some designs of pre-chamber engines, organized rotation about the pre-chamber axis is also called swirl. In the engine where swirl within the pre-combustion chamber is important, the flow into the pre-chamber during the compression process creates the rotating flow.

\subsection{Swirl Measurement}

The nature of the swirling flow in an actual operating engine is extremely difficult to determine. Accordingly, steady flow tests are often used to characterize the swirl. Air is blown steadily through the inlet port and valve assembly in the cylinder head of an appropriately located equivalent cylinder. A common technique for characterizing the swirl within the cylinder is to use a light paddle wheel, pivoted on the cylinder centerline (with low friction bearings), mounted between 1 and 1.5 bore diameters down the cylinder. The paddle wheel diameter is close to the cylinder bore. The rotation rate of the paddle wheel is used as a measure of the air swirl. Since this rotation rate depends on the location of the wheel and its design, and the details of the swirling flow, this technique is being superseded by the impulse swirl meter. A honeycomb flow straightener replaces the paddle wheel. It measures the total honeycomb exerted by the swirling flow. This torque equals the flux of angular momentum through the plane coinciding with the flow-straightener upstream face.

For each of these approaches, a swirl coefficient is defined which essentially compares the flow's angular momentum with its axial momentum. For the paddle wheel, the swirl coefficient $\mathrm{C}_{\mathrm{s}}$ is defined by 


$$
C_{s}=\frac{\omega_{p} B}{v}
$$

where $\omega_{\mathrm{p}}$ is the paddle wheel angular velocity $\left(=2 \pi \mathrm{N}_{\mathrm{p}}\right.$, where $\mathrm{N}_{\mathrm{p}}$ is the rotational speed) and the bore $\mathrm{B}$ has been used as the characteristic dimension. The characteristic velocity, $v_{0}$, is derived from the pressure drop across the valve using an incompressible flow equation [5]:

$$
v_{0}=\left[\frac{2\left(p_{0}-p_{c}\right.}{\rho}\right]^{1 / 2}
$$

or a compressible flow equation:

$$
\left.v_{0}=\left\{\frac{2 \gamma}{\gamma-1} \frac{p_{0}}{\rho_{0}}\left[1-\left(\frac{p_{c}}{p_{0}}\right)^{(\gamma-1 / \gamma}\right)\right]\right\}^{1 / 2}
$$

where the subscripts ${ }_{0}$ and ${ }_{c}$ refer to upstream stagnation and cylinder values respectively. The difference between the equations is usually small.

\subsection{Swirl Production}

There are actually two general ways of producing swirl during the induction process. Firstly, the flow is discharged into the cylinder tangentially towards the cylinder wall, where it is deflected sideways and downward in a swirling motion. In the other one, the swirl is largely generated within the inlet port: the flow is forced to rotate about the valve axis before it enters the cylinder. The former type of motion is achieved by forcing the flow distribution around the circumference of the inlet valve to be non-uniform, so that the inlet flow has a substantial net angular momentum about the cylinder axis. The directed port and the deflector wall port are two common ways of achieving this result. The directed port brings the flow toward the valve opening in the desired tangential direction. Its passage is straight, which due to other cylinder head requirements restricts the flow area and results in a relatively low discharge coefficient. The deflector wall port uses the inner side wall to force the flow preferentially through the outer periphery of the valve opening in a tangential direction. Since only one wall is used to obtain a directional effect, the port areas are less restrictive [6].

Flow rotation about the cylinder axis can also be generated by masking off or shrouding part of the peripheral inlet valve open area. A mask or shroud is often used on the valve in research engines as changes can readily be made. In production engines, the added cost and weight, problems of distortion, the need to prevent valve rotation, and reduced volumetric efficiency make masking the valve an unattractive approach. The more practical alternative of building a mask on the cylinder head around part of the inlet valve periphery is used in production of spark-ignition engines to generate swirl. It can easily be incorporated in the cylinder head casting process.

\subsection{Swirl Adapter}

The swirl adapter is theoretically placed inside the intake port of the CamPro Engine Model. The Adapter angle is set to $30^{\circ}$ to force the charge to bounce off the wall of the port to create swirl. The ramp is design based on the inside surface area of the intake manifold. Since 
the inside of the CamPro intake port is oval and is considered as directed intake port, the charge should not have any problem to create swirling. The adapter was chosen due to its ability to plug in and out of the system. This will help in the future if there is any rendition intended to be done on the manifold or the adapter itself. The movement of the swirl adapter is locked by the surface of the cylinder head so that it does not go into the combustion chamber. The design of the adapter is shown in Fig. 2 and the adapter placement is shown in Fig. 3.

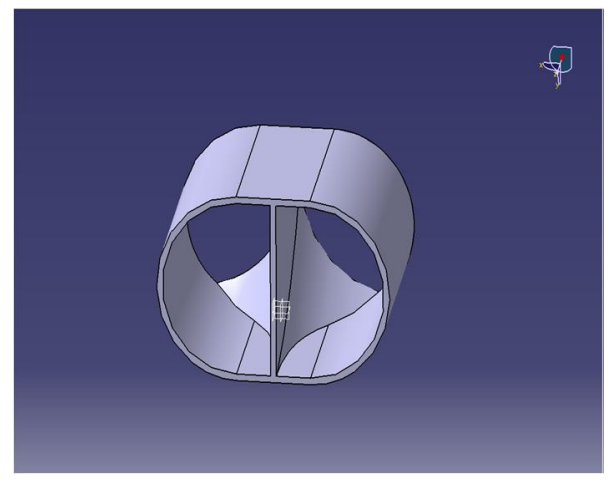

Fig. 2: Swirl adapter.

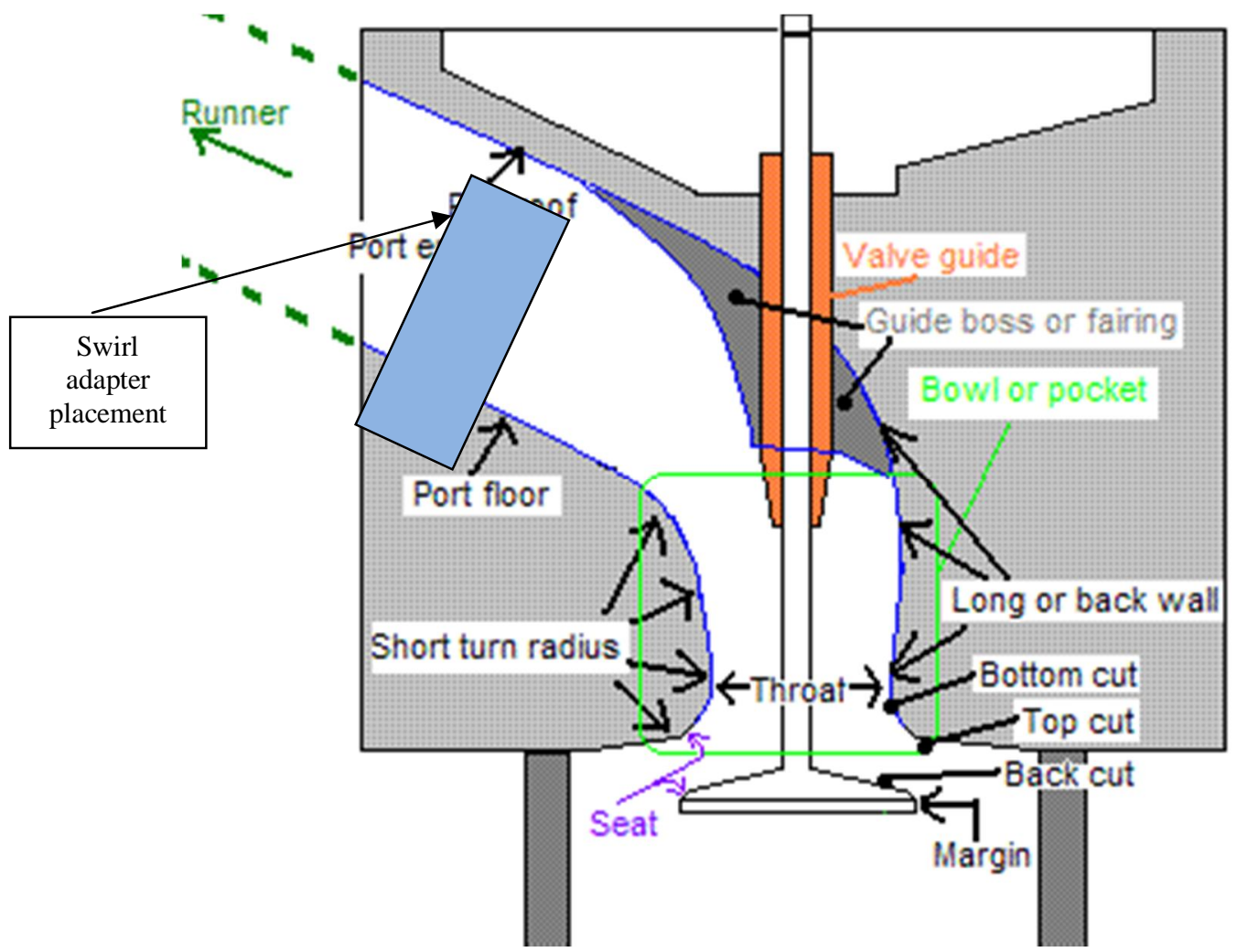

Fig. 3: Swirl adapter placement. 


\subsection{Design and Fabrication of Swirl Adapter}

In order to design the adapter a proper intake manifold is needed to estimate the angle of the ramp. The intake manifold is redesigned by using CATIA and the adapter is designed according to the inside surface of the intake manifold. The ramp is estimated to be $30^{\circ}$ of the floor to allow it to deflect in accordance to the wall of the intake manifold.

The fabrication of the Swirl Adapter is done by using a CNC Milling Machine coded by CATIA. CATIA generates a G-CODE with the design that had been done and the codes are used on the CNC Milling Machine. Before applying the codes on to the machine a series of test must be done using dummy software on a separate computer. This is to ensure that the milling process runs smoothly without damaging the work piece or the tools. The simulation is thoroughly checked step by step to determine and predict its movement.

\section{DISCUSSION AND ANALYSIS}

The actual swirl adapters were placed inside the intake manifold and tested on the Engine Test Bed using eddy current dynamometer. The data are obtained for both the Swirl CAMPRO Model and the Normal CAMPRO Model. Figure 4 shows that the swirl is generated in the initial part of the engine speed. It starts off with $7.017 \times 10^{-14}$ and gradually decreases. When the speed reaches $1500 \mathrm{rpm}$ the swirl is completely gone since at higher speed the swirl process is not significant. While in Fig. 5 as expected there is no swirl generation as the mixing process totally depended on normal turbulence only.

New Case $\quad$ C:DOCUME 1UUAN 1LOCALS $\sim 1$ Temp 4 MacroDlg33269.xml $\quad$ GT-POWER v6.1.0 19-MAR-08 02:49:13

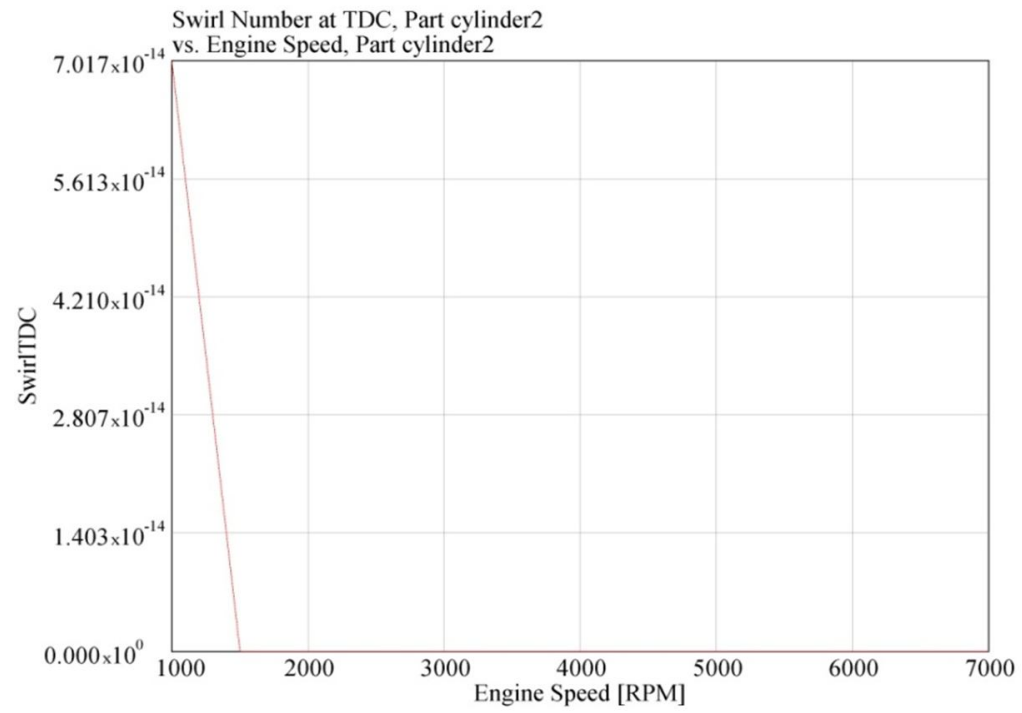

Fig. 4: Swirl CAMPRO: Swirl versus Engine Speed. 
New Case

C: DOCUME 1 VUAN $\sim$ LOCALS $\sim 1 \mid$ Temp MacroDlg33279.xml

GT-POWER v6.1.0 19-MAR-08 02:52:58

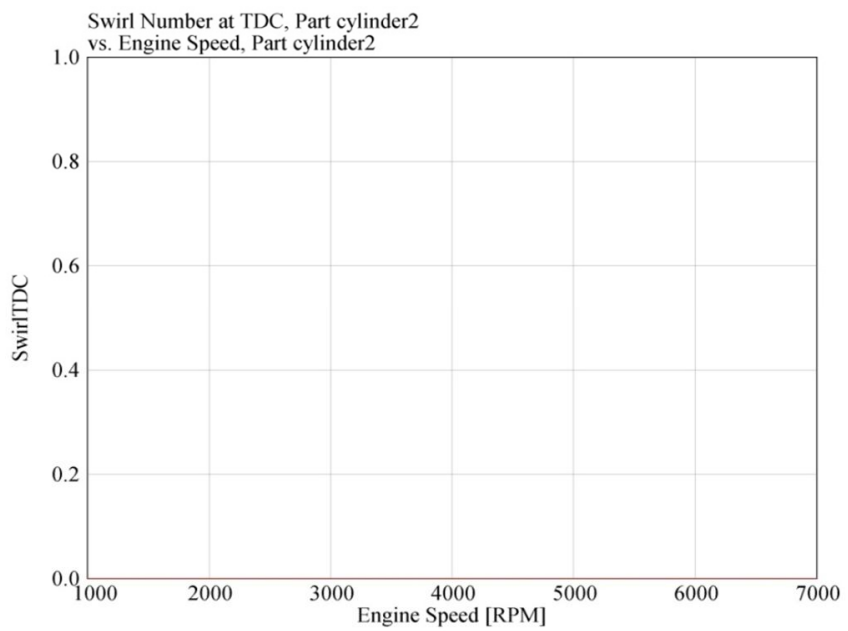

Fig. 5: Normal CAMPRO: Swirl versus Engine speed.

The specific fuel consumption shows the effectiveness of an engine using the fuel supplied to produce work [7]. From the Fig. 6 and 7, it can be deduced that the specific fuel consumption of the engine with swirl is lower than the normal CAMPRO model. The swirl effect shows that it has lower fuel consumption i.e., more fuel economy than the Normal CAMPRO engine. Even at higher rpm, the figures show that the swirl model saves more fuel than the normal model.
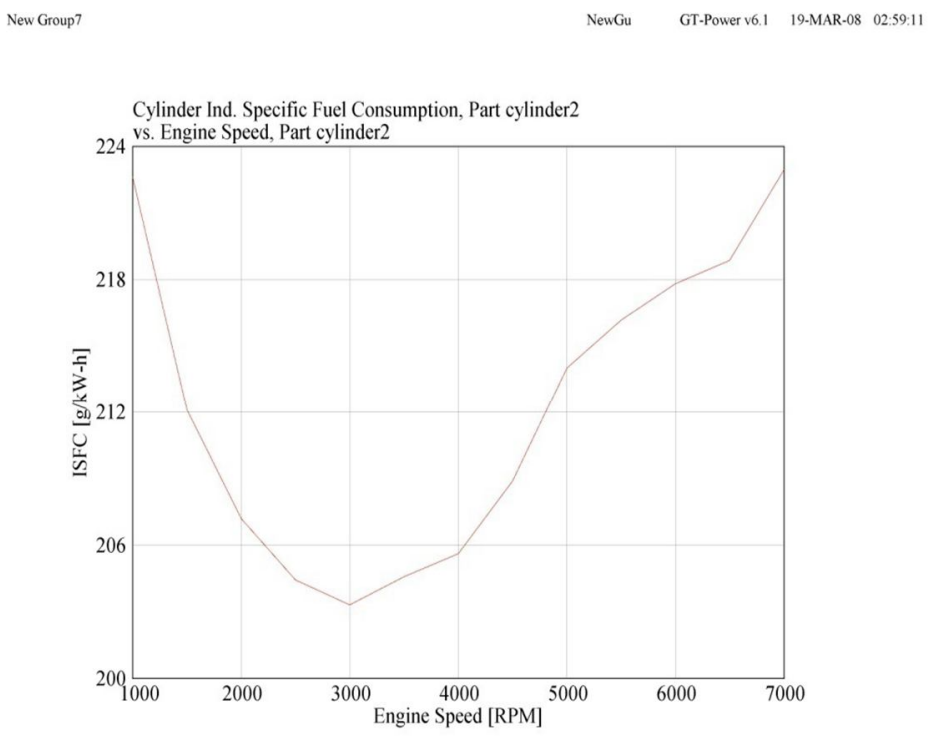

Fig. 6: Swirl CAMPRO: Indicated Specific Fuel Consumption versus Engine Speed. 

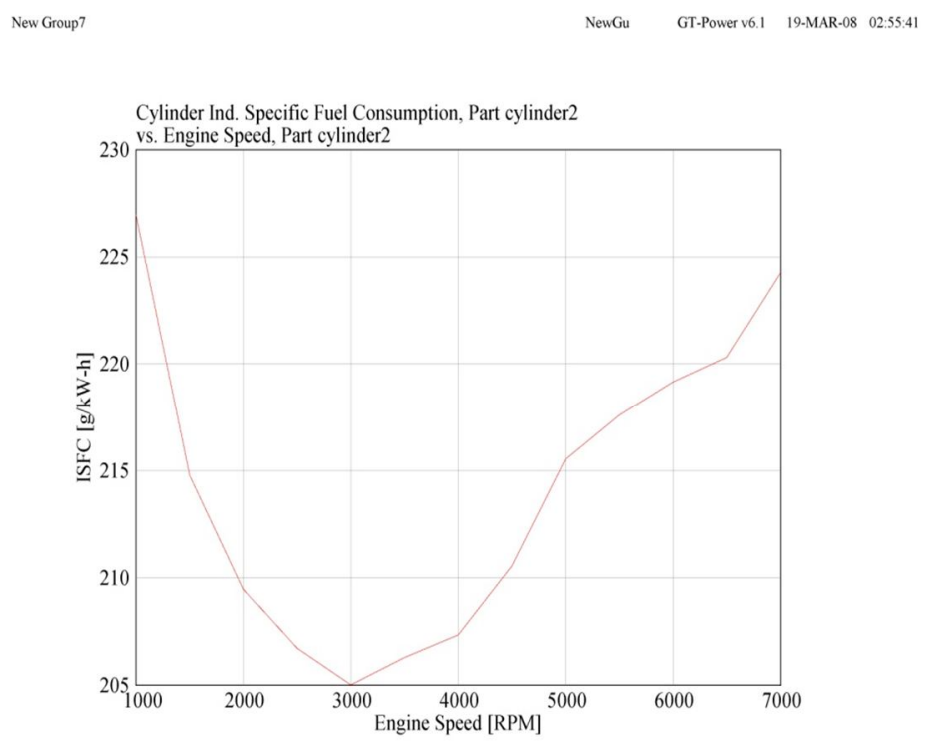

Fig. 7: Normal CAMPRO: Indicated Specific Fuel Consumption versus Engine Speed.

\section{CONCLUSION}

Investigation of the swirl effect on CAMPRO engine is performed and the result is compared with the normal engine. The effect of swirl comparing to normal turbulence shows an increase in the power as well as torque during the idle and cruising speed while it decreases rapidly in the acceleration speed. This happens due to the inability of the swirl adapter to generate swirl at higher wind flow velocity during the higher throttle opening condition.

The Brake Specific Fuel Consumption is considerably lower at the lower speed but increases above the normal aspirated graph as the speed goes above $3500 \mathrm{rpm}$.

\section{REFERENCES}

[1] http://www.proton.com/innovation/rnd/campro.php, 2005.

[2] Gamma Technologies, GT-Suite, http://www.gtisoft.com, 2004.

[3] GT-suite V6.1 User's Manual, Gamma Technologies, 2004.

[4] Heinz, H., Advanced Engine Technology, Arnold, (1995).

[5] Ohata, A., and Ishida, Y., "Dynamic Inlet Pressure and Volumetric Efficiency of Four Cycle Four Cylinder Engine” SAE paper 820407, SAE Trans., vol. 91, (1982).

[6] Ganesan, V., Internal Combustion Engines Second Edition. Mc Graw-Hill., (2004).

[7] Kyung-H L, Kisung K.(2001), "Influence of Initial Combustion In SI Engine on Following Combustion Stage and Cycle-By-Cycle Variations in Combustion Process". International Journal of Automotive Technology 